\title{
Biosphere Reserve Concept Implementation for Creating Sustainability
}

\author{
Y. Purwanto \\ Hari Nugroho \\ Anang Setiawan Achmadi
}

Esti Munawaroh

Corresponding email
Ethnobiology Research Group, Research Centre for Biology, Indonesian Institute of Sciences, Cibinong, Indonesia

Research Centre for Biology, Indonesian Institute of Sciences, Cibinong, Indonesia

Research Centre for Biology, Indonesian Institute of Sciences, Cibinong, Indonesia

Research Center for Plant Conservation and Botanical Gardens Indonesian Institute of Sciences, Bogor, Indonesia

mab-lipi@mab-indonesia.com

\begin{abstract}
The main priority of UNESCO MAB program is to emphasize the implementation of biosphere reserve concept for achieving sustainable development. Biosphere reserve is a concept of site management to harmonize the needs for conservation of both land and coastal ecosystem with the need for economic development in the basis of research on the utilization of natural resources, including cultural resources recognized by UNESCO MAB Program in order to promote a balanced relationship between human and the nature. Principally, the concept of biosfer reserve is applied to bring the conservation of biological diversity into line with sustainable development for achieving a balanced relationship between human and the nature.

The advantage of applying the biosphere reserve concept lays on the excellent combination of its three functions, namely: (1) The function associated with conservation of biological resources, ecosystems, and cultural diversity; (2) The function associated with development that supports and enriches sustainable economic development through an ecologicaly and culturally wise approach; and (3) The function associated with provision of logistics supports for various activities related with conservation and sustainable development, in a local, regional, national, or global context, including research, education, training, and monitoring.

In implementing those three functions integratively, a zonation approach is applied, in which the site of biosphere reserve is devided into three different areas with specific functions and roles: (1) The core area: It is the area for conservation and it must have a firm, long-term legal protection for preserving the biodiversity, monitoring the undisturbed ecosystems or undertaking non-destructive research, and other "passive" activities such as education and training and ecosystem services; (2) The buffer zone: It is the area encircling or adjoining the core area that is determined to provide protection to the core area against the negative impacts of human activities; and (3) The transition area: The transition area. It is typically the largest part of the biosphere reserve area fuctioning to develope cooperation with local communities. It is established side by side with the buffer zone and this area is a place to develope models for sustainable development and develop an appropriate management of natural resources for the area. Biosphere reserves are used as a place to test and build a sustainable way of life through integrated programs of natural resources
\end{abstract}


management and biodiversity conservation, with the objective to contribute in reducing poverty and increasing the living standard, especially of rural communities. In addition, the implementation of the biosphere reserve concept is also aimed to help reducing the loss of biodiversity, facilitating scientific development and bulding the capacity in the context of providing services neccessary for ecological sustainability.

Keywords: Biodiversity, biosphere reserve, logistic support, sustainable development, zonation system

\section{INTRODUCTION}

National Committee for Indonesian MAB Programs is a focal point for the implementation of the programs and missions of UNESCO MAB in Indonesia coordinated by the Indonesian National Commission for UNESCO (KNIU) that has an official base in the Ministry of Education and reports its activities to the Indonesian Ambassador for UNESCO in Paris. As for the implementation of the MAB programs and other programs related to sciences in Indonesia, the Indonesian government has assigned the Indonesian Institute for Sciences (LIPI) to manage the task. Further, in an ex officio condition, the Head of LIPI deliveres the task to the Deputy of Life Sciences. In performing its duties, the National Committee for MAB Program should consult with the UNESCO Regional Office in Jakarta. Thus, the MAB programs is basically also the national programs that must be taken by Indonesia as an obligation of being one of UNESCO members. Essentially, the MAB Programs hold the mission of ensuring a harmonious, balanced relationship between human and their natural environment (MAB-UNESCO, 2015).

Indonesian MAB Program has a long history, dating back to 1972, a few years after the International MAB Program of UNESCO was established in 1968. The National Committee for Indonesian MAB has the mandate to implement the missions, programs and activities of MAB in Indonesia, especially in relation with the biosphere reserves. The MAB Program is atempting to use biosphere reserves as a vehicle to implement the goals of the Convention on Biological Diversity (CBD) resulted from the 1992 Earth Summit, and emphazised further through Agenda 21, Sustainable Development and the Millennium Development Goals (MDGs). It is believed that biosphere reserves are important sources of information and data where people can learn (Batisse, 1996). This, therefore, may provide support to what promoted by the UNESCO through the "United Nations Decade on Education for Sustainable Development" (DESD 2005 - 2014) for which the "Main Line Action UNESCO MAB Year 2006 - 2007" was developed as an effort to promote "linkage between biodiversity and cultural diversity" (Purwanto et al., 2017).

MAB Program is chiefly developed to improve the quality of relationship between human beings and their environment on the basis of science and technology. Specifically it is aimed to overcome the problems of utilization of biological resources that cause degradation (biodiversity lost), decrease in environment quality and unplanned land use. Such problems mainly stem from the people intention to exploit biological resources for economic benefit rather than for socio-cultural and conservation reasons. Therefore, the establishment of MAB program has a mission to balance the seemingly conflicting goals of environmental conservation and socio-economic development as well as to mantain the noble values of a nation's culture. In short MAB program is designed to promote and demonstrate the balance of the relationship between human and the nature through landscape ecosystem approaches. 
The main priority of $\mathrm{MAB}$ program is to emphasize the implementation of biosphere reserve concept for achieving sustainable development. Biosphere reserves are used as a place to test and build a sustainable way of life through integrated programs of natural resources management and biodiversity conservation, with the objective to contribute in reducing poverty and increasing the living standard, especially of rural communities. In addition, the implementation of the biosfer reserve concept is also aimed to help reducing the loss of biodiversity, facilitating scientific development and bulding the capacity in the context of providing services neccessary for ecological sustainability.

\section{MAB Program:}

The MAB Indonesian programs consists of three action plans:

1. Management of landscapes based on ecosystem approaches for integrating the management of land, water and biodiversity for conservation and a fair and sustainable use.

2. Empowernment of institutions and human resources for promoting the sustainable use of natural resources (land, water and biodiversity) to improve the interaction quality of human and the environment.

3. Integration of fundamental scientific approaches and socio-cultural approaches for the conservation and sustainable management of biological resources, land and water.

In order to implement those three actions plans; the National Committee for Indonesia

MAB Program develops programs that are based on:

(1) The Seville Strategy: As an effort to achieve the missions of MAB Program, in 1995 UNESCO conducted an international experts meeting in Seville, Spain that produced the Seville Strategy. This Strategy recommends actions that must be taken for developing biosphere reserves up to the $21^{\text {st }}$ century. It focuses on some priorities at international, national and local levels, namely: (a) the use of biosphere reserves for conservation of natural resources and cultures, (b) the use of biosphere reserves as a model of appropriate landscape management for sustainable development; (c) the use of biosphere reserves for research, monitoring, education and training, and (d) the implementation of biosphere reserve concept (MAB-UNESCO, 1995).

(2) The MAB International Program: The $17^{\text {th }}$ meeting of the MAB International Coordinating Council (MAB-ICC) held in March 2002 has resulted an agreement that the world biosphere reserves network is a main tool for implementing the MAB activities that are grouped into two "Main Line of Action" (MLA): (a) MLA-1 focuses on the management of natural resources and sustainable development. In this concept, biosphere reserves are used as a place to test and build a sustainable way of life through integrated programs of natural resources management and biodiversity conservation, with the objective to contribute in reducing poverty and increasing the living standard, especially of rural communities. Biosphere reserves are also a place to demonstrate ecosystem approaches that are advised and being developed by the CBD. Such approaches are considered as a key component in the implementation of the WSSD (World Summit on Sustainable Development); (b) MLA-2 focuses on the efforts to enhance scientific basis, human resources capacity and communication. MLA-2 is designed to help reducing loss of biodiversity by developing science and building the capacity in the context of providing services for sustainability. Research and the development of human resources capacity at both institutional and individual levels are significant contributions for achieving the goals. 
(3) The Madrid Action Plan: The MAB Congress held in Madrid on February 2008 have produced Madrid Plan of Action stating that biosphere reserves should be able to answer the following challenges (MAB-UNESCO, 2008): (a) Changes in the global climate (Global Climate Change), (b) Acquirement of better ecosystem services (Ecosystem Services) and (c) Anticipation of the urbanization. The congress also reaffirmed the "Seville Strategy" concerning the potential of biosphere reserves as learning facilities to face problems on the diminishing traditional knowledge and cultural diversity, the demographic conditions, and the anticipation of environmental changes through both adaptation and mitigation measures. This is very important since biosphere reserves can facilitate a balanced combination of the needs for ecosystems conservation and sustainable development through the three related main pillars, i.e. "conservation, research and science, and development". In addition to Madrid Action Plan (MAP) the Congress also successfully produced "Madrid Declaration" recommending four interrelated principal issues, namely: (1) cooperation, management and communication, (2) zonation and zonation interrelationship, (3) knowledge and capacity building of human resources, and (4) partnership.

(4) Lima action Plan: Lima Action Plan consists of 5 areas strategies that aimed to reach agenda of SDGs 2030 (MAB-UNESCO, 2016). The 5 strategies areas are: (a) The WNBR consisting of effectively functioning models for sustainable development; (b) Inclusive, dynamic and result oriented collaboration and networking within the MAB Program and the WNBR; (c) Effective external partnerships and sufficient and sustainable funding for the MAB Programme and the WNBR; (d) Comprehensive, modern, open, and transparent communication, information and data sharing; and (e) Effective governance of and within the MAB Programme and the WNBR

(5) Help Member States and stakeholders to urgently meet the Sustainable Development Goals through experiences from the WNBR, in particularly through exploring and testing policies, technologies and innovations for the sustainable management of biodiversity and natural resources and mitigation and adaptation to climate change.

(6) Contextual state of Indonesia. MAB programs should be developed in the contex of actual conditions of Indonesia, so that the impacts can significantly touch the Indonesian people.

\section{Biosphere Reserve}

Biosphere reserve is a concept of site management to harmonize the needs for conservation of both land and coastal ecosystem with the need for economic development in the basis of research on the utilization of natural resources, including cultural resources recognized by UNESCO MAB Program in order to promote a balanced relationship between human and the nature. Principally, the concept of biosfer reserve is applied to bring the conservation of biological diversity into line with sustainable development for achieving a balanced relationship between human and the nature. In its development the concept has been adopted by many countries to manage their conservation areas and the surroundings.

Following its release, the program has amazingly grown in number from 324 biosphere reserve held by 82 countries in 1995 to 430 biosphere reserves held by 95 countries in 2002 and a further increase to 553 biosphere reserves maintained by 107 countries in 2009, and 701 biosphere reserves in 124 countries in 2019. This development indicates that the concept is a suitable and measurable approach for site management in order to conserve natural resources and to achieve sustainable development. It is also believed that the concept of biosphere reserve management has specific values for identifying, characterizing, 
valuating, demonstrating, and integrating conservation within the sustainable development context.

The advantage of applying the biosphere reserve concept lays on the excellent combination of its three functions (Figure 1), namely:

(1) The function associated with conservation of biological resources, ecosystems, and cultural diversity. This function provides contributions to the conservation of landscapes, ecosystems, species, and germplasms, as well as cultural diversity;

(2) The function associated with development that supports and enriches sustainable economic development through an ecologicaly and culturally wise approach.

(3) The function associated with provision of logistics supports for various activities related with conservation and sustainable development, in a local, regional, national, or global context, including research, education, training, and monitoring.

In implementing those three functions integratively, a zonation approach is applied, in which the site of biosphere reserve is devided into three different areas with specific functions and roles (Figure 1):

1. The core area: It is the area for conservation and it must have a firm, long-term legal protection for preserving the biodiversity, monitoring the undisturbed ecosystems or undertaking non-destructive research, and other "passive" activities such as education and training. The core areas of 16 biosphere reserves in Indonesia, the core area is composed by national park, natural reserve, wildlife reserve, forest park reserve, nature tourism park, forest protection and forest conservation of private sector. However, this doesn't mean that the core area must always be a conservation area managed by government, but it can be a site owned by individuals, non-governmental organizations or institutions, communities, or traditional inhabitans that is alocated for conservation purposes. In principle, a core area must be a conservation area or a protected area supported formally by a governmental regulation or informally by traditional law (traditional institutions). In Giam Siak Kecil-Bukit Batu Biosphere Reserve, which is the $7^{\text {th }}$ Indonesian biosphere reserve, the core area is composed by a conservation areas (Suaka Margasatwa Giam Siak Kecil and Bukit Batu) and a production forest set for permanent conservation uses and managed by private sector Sinar Mas Forestry.

2. The buffer zone: It is the area encircling or adjoining the core area that is determined to provide protection to the core area against the negative impacts of human activities. The area of buffer zone can be a site owned by individuals, communities, institutions or others. The managemnet of this area is conducted by the owner, but it should be run in accordance with the government regulation. Basically, activities that can be done in this area are those that are sound ecologically, such as research, education, training, ecoturism, and sustainable utilization of biodiversity or other renewable resources.

3. The transition area: It is typically the largest part of the biosphere reserve area fuctioning to develope cooperation with local communities. It is established side by side with the buffer zone and may be owned by individuals, organizations, private institutions, or other legal bodies. This area is a place to develope models for sustainable development, in which the owner(s) together with relevant stakeholders develop an appropriate management of natural resources for the area. 


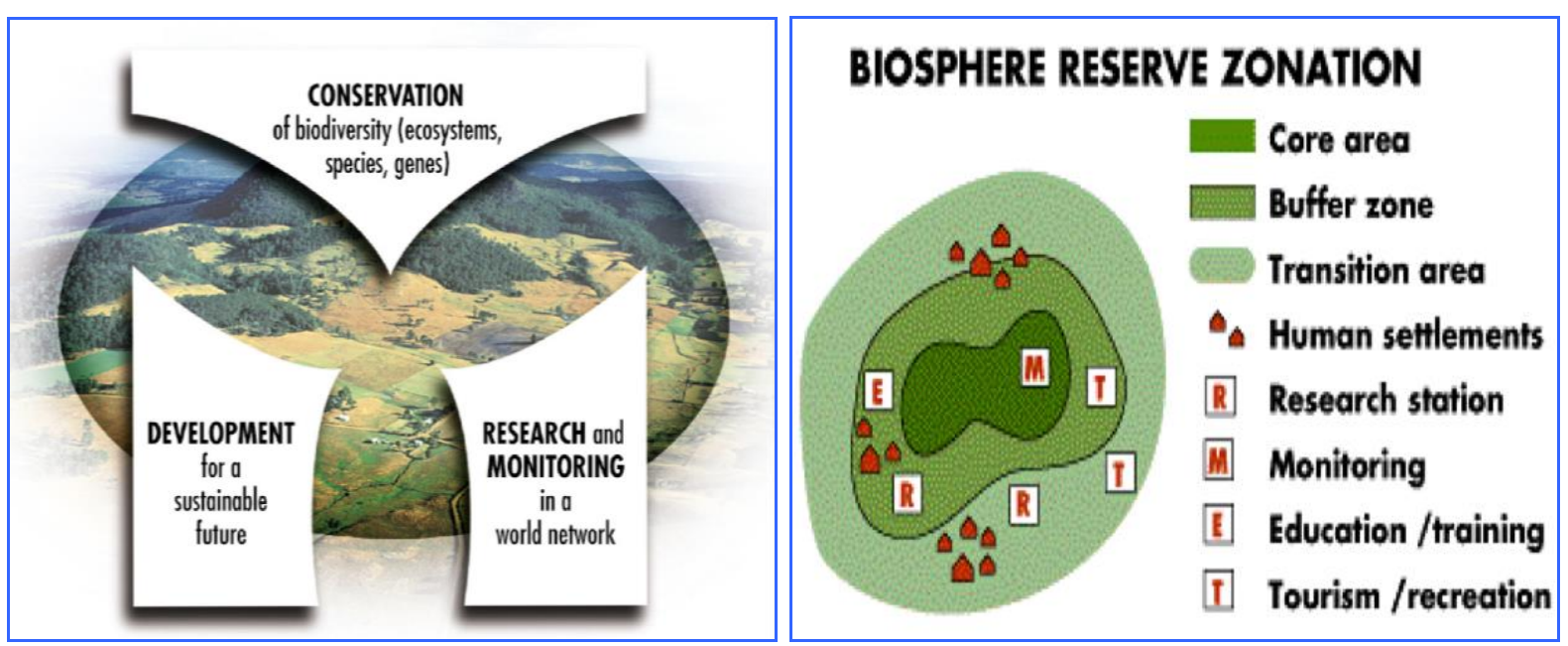

Figure 1. Function and zonation system of biosphere reserve

[Sumber: MAB UNESCO, 2019]

The buffer zone and the transition area serve as a corridor whose function is to protect and ensure the functions of the core as a conservation area of the natural biological resources within. For effective managemnet reasons, there shold be a clear border line between the existing zones, since the development of each zone may be implemented in a different way.

\section{Spatial Site Arrangement and Development}

Integrated spatial site arrangement is required for achieving sustainable and constructive management of natural biological resources and their environment. In term of biosfere reserves the arrangement is implemented by means of interrelated and intersupportive zones, while integrated site divelopment is done through suitable zonation. Principally, biosfere reserve zones consist of a conservation zone as the strickly protected core area surrounded by a buffer zone that emphasizes the environmentally friendly management, and finally a transition zone as the outer layer of the biosfere reserve that serves as an area of cooperation to develop potential species of economic and ecological values to promote sustainable development. The implementation of spatial site arrangement and development is therefore managed by means of bioregional plan approach that integrates biodiversity conservation into sustainable development.

The concept of biosphere reserve management has to be designed properly in order to deal with the challenges of harmonizing the goal of biodiversity conservation with the needs for socio-economic development and at the same time also preserving the cultural values existed in the area. This means that, in addition to suitable spatial site arrangement, integrated site management have to be based also on the participation of all relevant stakeholders, including the surrounding communities Pio et al., 2012).

One of the advantages of applying biosphere reserve concept in managing a conservation area is that the management of the conservation zone (core area) is not merely focusing on keeping and protecting the zone, but there should also be integrated efforts to develop the surrounding areas. In this regards, the establishment of the buffer and transition zones is in fact aimed to secure the conservation area and at the same time to improve the quality of the surrounding areas through economic development that utilizes the potency of natural resources existed in the site. For this to happen, the following steps are needed:

(1) Spatial arrangement of the site according to a zonation model that emphasizes conservation and development. 
(2) Management with ecosystem approach. This means that in addition to protecting the conservation area, there should be efforts to develop the surrounding areas (buffer and transition areas) for securing the conservation area and integrating the cultural diversity with biodiversity, especially in term of the roles of traditional knowledge in the ecosystem management.

(3) Management with participation approach that emphasizes the involvement of relevant stakeholders, most importantly the local communities, in the management of the site;

(4) Spatial site arrangement based on the related functions and roles for avoiding conflict of interest in the utilization of natural resources;

(5) Management based on scientific studies (research) with appropriate monitoring and evaluation activities;

(6) Implementation of the site management that prioritizes the needs of improving the community life quality through the utilization of potential natural resources without disturbing conservation efforts in a sustainable development framework.

\section{Integration of Conservation and Development}

So far, there has been important innovation in the management of conservation areas. New methodologies that facilitate the involvement of stakeholders in the decision making and in resolving conflicts have grown significantly and the related regional approaches have drawn bigger attention. Interesting current development in the management of conservation areas is the change in the managerial focus from merely conservation motivation into more acceptable combination of conservation and development through a wider cooperation within stakeholders and a suitable spatial site arrangement (Bioret et al., 1998).

Integration between conservation and development efforts in a site management supports the interrealted functions of the site. Conservative function is dealing with the preservation of genetic resources, species, ecosystems and landscapes. Developmental function is important for strengthening economic development in order to improve the life quality and the welfare of the related communities. Meanwhile, supportive function has something to do with the improvement of the site management by means of innovation, research, education and training, so that all management measures are taken based on the results of the studies or research and improved quality of human resources of the related stakeholders.

Physically, the management of biosphere reserve that integrates conservation areas and economic development areas consists of three interrelated elements, namely:

(1) Conservation area as the core area of the biosphere reserve: It must be sufficiently protected for the purpose of conserving the biodiversity, monitoring the ecosystem, undertaking non destructive research and other activities that have minimum impact to area. It also important for the balance of ecosystems within the site. The management authority of this area is held by the Forestry Department.

(2) Buffer zone: It is an area encircling or adjoining the conservation area that has to be clearly defined and used for cooperative activities that do not bring about ecological conflicts.

(3) Transition area: It is an area encircling or adjoining the buffer area that is used for developing various potential natural resources in a sustainable development framework. Stakeholders consisting of the local government, private bodies and the local community are working coopertively in this area to manage and develop natural resources sustainably. 


\section{The Management of Biosphere Reserve}

Appropriate management of biosfer reserve should be based on the principle of "multi-stakeholder management", due to the variation of landscape and stakeholders (Figure 2). Therefore, it would seems inappropriate if the National Committee for MAB Program develops a biosphere reserve management plan without involving the stakeholders. The plan should provide reference for directing the development course of the biosphere reserve in accordance with its conservation and sustainable use objectives. Further actions necessitate the development of suitable action plan as a reliable guidance for all stakeholders to contribute in the activities relevant with the time and spatial frames. In this regard, the management plan is actually a reference document that can be modified according to the actual needs and development. It is also righly termed as living document since it can continuosly be developed according to the dynamic of the overwhelming situation and needs.

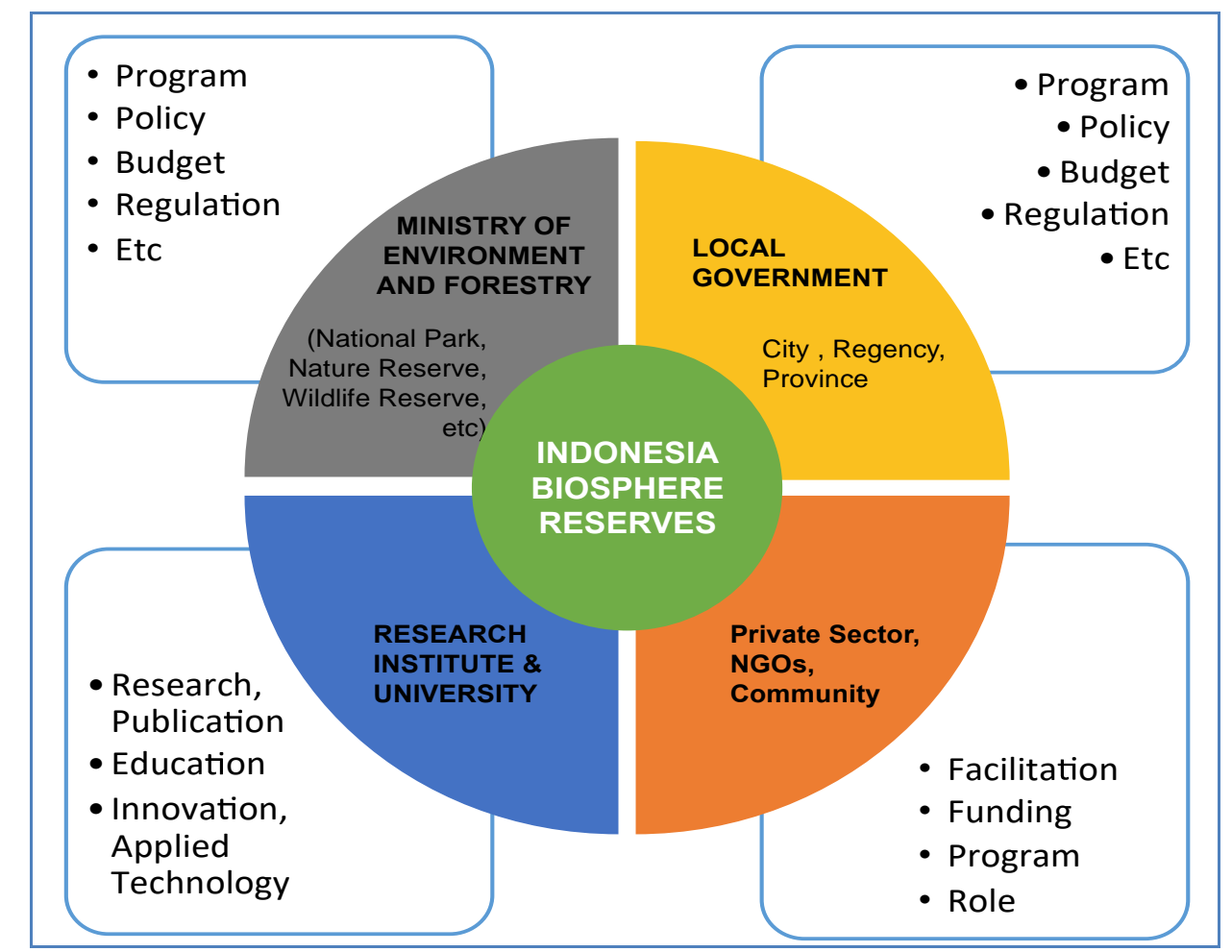

Figure 2. Multisatkeholders management in Biosphere Reserve development

[Sumber: MAB Indonesia, 2019]

A site determined to be a biosphere reserve must be able to function as an agent of integrating and coordinating all stakeholders' efforts without compensating the historical ownership rights of land or resources in order to synchronize its managemnet. Therefore, the development of management plan for Biosphere Reserves should involve all parties, including Department of Forestry (PHKA), the local government, Forestry Agency, scientists (Research Institute and University), NGOs, private bodies, the local communities and general users of the bioresources of the area. In line with this, it is clear that to develop management plan of a biospher reserve, a multistakeholder and multi-aspect approach is needed to produce comprehensive programs of securing and utilizing biodiversity for the sake of community welfare.

It appears, therefore, that the management of a biosphere reserve has no standardisized legal rule or specific regulation, since biosphere reserve management lays on 
the interface (interaction) principles of scientific basis, socio-economic conditions and local existing cultures. Thus, the management with biosphere reserve concept is implemented through a compromizing approach to search for the best possible ways by involving all related parties including local communities in the process of decision-making and further implementation of required actions. This approach has an international dimension and reference. For example the application of the zonation model and its developmental actions will certainly involve partners of diverse origins in order to provide better protection to site of the biosphere reserve. This follows that mutual dialogue and consensus within stakeholders are needed to produce an acceptable management plan.

\section{Steps for Management Planning of Biosphere Reserve}

For the management of the Biosphere Reserve, there is a need to determine comprehensive managerial steps that are composed in a dynamic "management plan" defining the integrated management of the three established zones: core area, buffer zone and transition area (Figure 3). The required management plan has actually been developed in conjunction with the preparation of obtaining the status of biosphere reserves, but it is still far for being a perfect document. Accordingly, it needs to be revised by the stakeholders integratively with several focus as follows: (a) inventory on the strength and weaknesses and the related problems; (b) evaluation of all managerial policies and activities that have been applied and implemented; (c) development of the plan and the direction of management; (d) establishment of work plan; and (e) implementation of developmental actions.

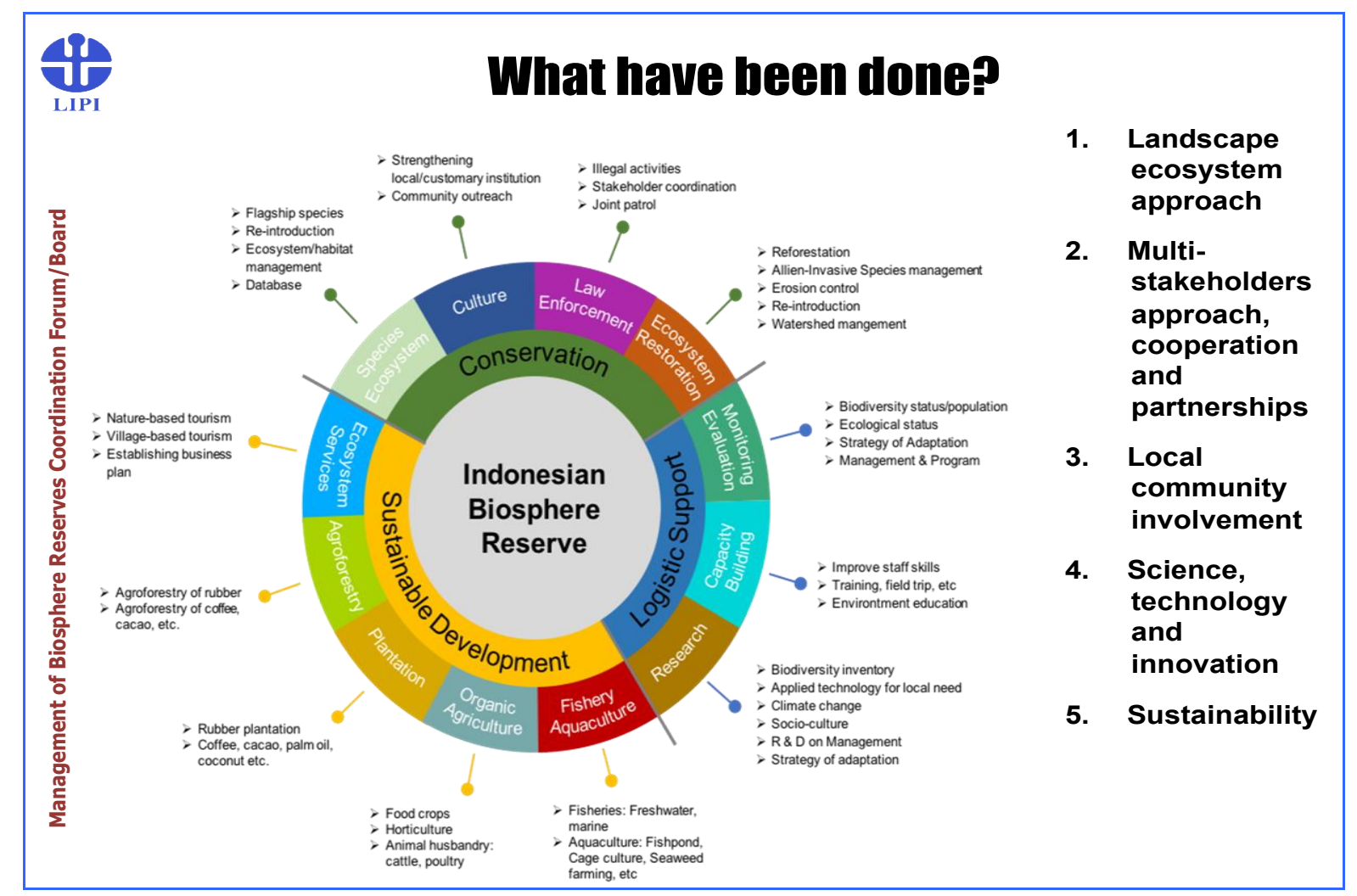

Figure 3. Management plan adapted the function of biosphere reserve

[Sumber: MAB Indonesia, 2019] 
How to implement the management plan and action plan in the field? We have strategic approach consists of: (1) Landscape ecosystem approach; (2) Multi-stakeholders approach, cooperation and partnerships; (3) Local community involvement; (4) Science, technology and innovation; and (5) Sustainability (Figure 3)

\section{A. Management of the Core Area}

Activities conducted in this area must be in line with the principal goals of the core area management, i.e. preserving the biodiversity by enforcing a full and strict protection measures as commonly done in other conservation areas. Human activities that utilize natural resources contained in this area are strictly controlled. However some scientific activities can still be done, such as research, long-term ecosystem monitoring or management practices based on the principles of an ecological balance, (e.g. Ecotourism activities have minimal impact to the environment) (Purwanto, 2008).

The management of the core area is fully organized and be the responsibility of the Department of Forestry. This paper suggests a few things that may be conducted in this area:

(a) Scientific exploration of biodiversity and other potency of the natural resources: This is very important for the management of biosphere reserve area that should be based on scientific data and reliable knowledge concerning the site.

(b) Identification of the cultural resources and the local knowledge of communities inside the site and the surrounding areas for the managemnet of the biological resources and their environment.

(c) Evaluation of various protection activities: Evaluation concerning the efficiency of various existing protection activities should be conducted since it can be considered as a function of possible threats and the vulnerabilities of the resources. It is important to evaluate various standardisized protection actions along with the insurance for their long term application, especially in relation with actual potential pressures, such as the impact of overexploitation viewed from the economic, cultural and environmental perspectives. It is a wise measure to move activities that cause negative impacts into the buffer zone. Similarly for the policies that favour a strategy of strengthening the efforts for securing the core area.

(d) Valuation of various important and potential biological resources to be developed into economic cultivation plants for the communities in the buffer and transition zones.

(e) Need for new paradigm for the management of conservation areas. It should be better understood that managing the conservation area means also managing the transition and buffer area for better protection of the conservation area.

(f) Establishment of research station

(g) Development of branding of biosphere reserve products

(h) Development of ecosystem services.

\section{B. Management Plan for Buffer Area}

The Biosphere Reserves has drawn clear border lines, including the border line of the core zone and the outer border line of trasition zone. Apart from the need to develop a management plan for the buffer zone, there are other important work that should be done for better management of this zone: 


\section{Identification of Knowledge}

(a) Inventory of the strength and the encountered problems and "need assessment" for developing the buffer zone.

(b) Identification of knowledge on production activities such as exstractivism of natural resources, agriculture, forestry, tourism and the impact on the biodiversity and other components.

(c) Inventory of current regulations that are related to the land use and spatial regional planning (RTRWP and RTRWK), and evaluation on the suitability of the land use planning with current existing practices.

(d) Identification of stakeholders involved in the buffer zone, including those managing the resources, institutional partners, private sector bodies, professional workers, researchers, the local government, and NGO's.

(e) Inventory of training and environmental education for the communities concerning the management of resources in the basis of biosphere reserve management concept.

\section{Evaluation}

This activity is in a close association with those of identification of knowledge and assessment of the whole activities conducted in the buffer area. Evaluation is an important step toward the determination of integrated steps for the zonation management of the biosphere reserve, especially in identifying the impacts resulted from production activities conducted in the buffer zone of the biosphere reserve. The evaluation includes:

(a) Evaluation of ecological impacts: This is to identify the kind of production activities conducted in this area that cause negative impacts to the core area and other areas, the kind of productions activities that have been in accordance with the sustainable use of the resources and the adaptation strategies that should be developed for the preservation of natural resources?

(b) Evaluation of economic impacts: This is to identify the kinds of production activities (biological resources management) conducted in the buffer zone that are adventigious economically.

(c) Evaluation of social impacts: This is to identify the impacts of production activities to various social aspects, such as employment opportunities (seasonal or long-term basis) and general life quality improvement (education, health, security, freedom, and others).

\section{Action Plan}

Following the identification of the strength and the problems asociated with the management of biosphere reserve, the next important step is to develop an "action plan" for improving the quality of relationship between the communities, natural resources and the environment. The action plan must provide an approach for integrating the needs for economic development wtih ecological and social interests through the involvement of the related stakeholders. In addition to the development of the action plan, there is a need to identify promising partners for future cooperation to implement pilot projects and developmental activities.

\section{The Implementation of Research and Pilot Project of Applied Research for the Development of Important and Potential Species in This Area}

Various applied research activities can be done in this area; among them are the development of ecotourism, silviculture of potential biological resources, and research on the suitability of land use. For the implementation of these applied research activities, a suitable 
"term of reference" is needed to provide guidance to those involved in the pilot project activities.

\section{Management Plan for the Transition Area}

Transition area of Biosphere Reserve covers a very large area. It is the area of development where various results of research and subsequent tests are brought into practices for supporting a sustainable management of resources. It is the also a place for active cooperation for researchers, managers, local people and other stakeholders in carrying out "pilot project" on production activities and management of other resources which are supportive to thesustinable development plan.

The first step that has to be done in the transition area is to undertake education, training, research and dissemination of information concerning the concept of biosphere reserves management. It is important to convince the communities in this area that the application of biosphere reserve concept is advantageous for the production activities conducted in this area. Therefore, this initial step should be appropriately designed in order to attract people and find their supports. The next following steps include:

1. Identification

(a) Identification of production activities and utilization of resources, e.g. agriculture, forestry, tourism, industries and so on.

(b) Identification and analysis of production activities and their impacts on ecological and socio-economic conditions, the region development and the suitability of the land with the related plan of land use.

(c) Identification of participants such as local communities, private bodies, scientists, financial institutions, and other stakeholders for synchronizing the vision and mission of sustainable development in the transition area.

(d) Identification the activities related to public awareness through training, education and dissemination of information in accordance with the action plan for transition area development.

2. Evaluation of production activities that is important to the communities within the area, including production activities that have minimal influence or impacts on the ecological condition, but providing economic benefits and are important for social life of the communities. The evaluation must also take into account the needs for promoting the sustainable use of biological resources.

3. Development of work plans and action plan that can significantly improve the local community economy. It is dificult to get people suppots on the concept of transition area development if there is no significant real results. The development of the work plan has to be based on the balanced between economic and ecological interests.

\section{Some Steps for the Management of Biosphere Reserves} include:

In general, some steps that must be taken for the management of Biosphere Reserve

(1) Identifying all stakeholders of Biosphere Reserve both for the buffer zone and transition zone and increasing the role of the private bodies in the management of the Biosphere Reserve.

(2) Building a mutual understanding on the vision, mission, and the common goals of Biosphere Reserve management. 
(3) Establishing the managing institution of Biospere Reserve and build strong coordination and cooperation between stakeholders.

(4) Revising the "management plan" of the Biosphere Reserve to be more comprehensive and integrated. Therefore, there is a need to carry out "need assessment" and adaptation strategies of development

(5) Developing the action plans and pilot project for buffer and transition zones development according to the existing local conditions..

(6) Conducting socialization of Biosphere Reserve management concept, education and training activities to the communities.

(7) Empowering of legal apect of Indonesian biosphere reserve (national level)

(8) Establishing cooperation (networking) on the management of biosphere reserve with various parties concerned with the implementation of the concept of biosphere reserve.

(9) Preparing proposals for fund rising to the potential donor institutions.

\section{Management Institution Forum/Agency}

The forum/agency consists of the "managers" representing the local government, administration, groups, private bodies, NGOs and scientists. In order to develop the Biosphere Reserves as a "laboratory for ideas" it is important useful to establish an ad-hoc working group to take the tasks of management forum/agency and to perform depth examination on specific topics.

The forum/agency has the following tasks: (1) Establish agreement on the scope of Biosphere reserve area (including zoning) based on the regional site spatial arrangement policy (district/municipal, province, or national), (2) Develop understanding on the vision, mission, and common objectives of Biosphere reserves management; (3) integrate the parties policies (planning) concerning the development of Biosphere reserves; (4) monitor the implementation of regulation by the parties relevant to the concept of biosphere reserve; (5) formulate plans and priorities for the management activities of biosphere reserve; (6) formulate solutions: conflict of interest between the parties, and (7) prepare the proposal: fun rising, and (8) carry out development activities.

\section{CONCLUSION}

The management of conservation areas should not be aimed solely to maintain and protect the conservation areas, but it should also emphasize integrated management approach of bioregional conservation area and the surroundings. Such approach has been developed by the UNESCO as a concept of Biosphere Reserves. The concept needs to be implemented so that the advantage may be useful for the management of the conservation areas and for the socio-economic and cultural interests of the surrounding communities. The advantages of the application of the concept lays on the balanced combination of the three functions, namely: (1) Function asociated wih the conservation of biodiversity, ecosystem and cultural diversity, (2) Function asociated wih sustainable economic development that is ecologically and culturally wise and (3) Function asociated with logistical support for various activities including research, education, training and monitoring issues related to the conservation and sustainable development at the local, regional, national and global levels.

For implementating of the Biosphere Reserve concept in a region, some steps are necessary, such as: (1) establishing the managing institution and legal aspect of biosphere reserve. Biosphere Reserve management is more appropriately done in the way of multi- 
stakeholder, (2) colaborative management is more suitable to manage biosphere reserve. The management of biosfer reserve is not in the form of structural organization, but it is the place of coordination (communication forum) of multi parties (3) In this coordination forum, a leading sector (government) is required, functioning as the coordinator of development planning of the biosphere reserve; (4) in the management of biosphere reserves, the coordinator does not have the right to contribute indecision making procces, because the decision is taken through a multi-party agreement, (5) The role of stakeholders outside the region of biosphere reserve is more suitable for the purposes of consultation, advocacy, human resource development (capacity building), funding support, and innovations that are relevant with the development of biosphere reserves concept.

\section{REFERENCES}

Batisse, M. 1996. Reserves de biosphere: un nouvel essor. Nature, Sciences et Societe 4(3): 268-272.

Bioret, F., Cibien, C., Geno, J.C., Lecomte, J. 1998. A guide biosphere reserve management: a methodology applied to French Biosphere Reserves. UNESCO, Paris, 48 p.

MAB-UNESCO. 1995. Seville strategy 1995. UNESCO, Paris.

MAB-UNESCO. 2008. Madrid action plan 2008-2013. UNESCO, Paris.

MAB-UNESCO. 2015. New strategy of MAB Program 2015-2025. UNESCO MAB Programme. Paris

MAB-UNESCO. 2016. Lima Action Plan 2016-2025. UNESCO MAB Programme. Paris

MAB Indonesia. 2019. Laporan Studi Penguatan Kelembagaan di Cagar Biosfer Giam Siak Kecil-Bukit Batu. Komite Nasional Program MAB Indonesia, Bogor.

Pio, D., Purwanto, Y., Subiantoro, G. (eds.). 2012. Are climate change and other emerging challenges being met through successful achievement of Biosphere Reserve Functions?. Proceeding of the $6^{\text {th }}$ Southeast Asia Biosphere Reserve Network (SeaBRnet) Meeting, Cibodas, West Java, $171 \mathrm{p}$.

Purwanto, Y. 2008. Rencana pengelolaan Cagar Biosfer Cibodas. Sarasehan Pengelolaan Cagar Biosfer Cibodas Sebagai Daerah Tujuan Wisata Alam. Balai Besar Taman Nasional Gunung Gede Pangrango, Jawa Barat.

Purwanto, Y., Sukandar, S., Nugroho, H., Supriyatno. 2017. Pedoman branding produk Cagar Biosfer di Indonesia. Komite Nasional Program MAN-UNESCO Indonesia, Bogor. 